\title{
Conformations of $\beta$-Amino Acid Residues in Peptides: X-Ray Diffraction Studlies of Peptides Containing the Achiral Residue 1-Aminocyclohexaneacetic Acid, $\beta^{3,3} \mathrm{Ac}_{6} \mathrm{C}$
}

Prema G. Vasudev, ${ }^{1}$ Rajkishor Rai, ${ }^{2}$ Narayanaswamy Shamala, ${ }^{1}$ Padmanabhan Balaram ${ }^{2}$

${ }^{1}$ Department of Physics, Indian Institute of Science, Bangalore 560 012, India

${ }^{2}$ Molecular Biophysics Unit, Indian Institute of Science, Bangalore 560 012, India

Received 10 December 2007; revised 28 January 2008; accepted 31 January 2008

Published online 13 February 2008 in Wiley InterScience (www.interscience.wiley.com). DOI 10.1002/bip.20957

\section{ABSTRACT:}

The conformational preferences of the 3,3-disubstituted $\beta$-amino acid residue, 1-aminocyclohexaneacetic acid $\left(\beta^{3,3} A c_{6} c\right)$ have been investigated by determining the crystal structures of the parent amino acid, the hydrochloride derivative, 10 protected derivatives and di and tripeptides. The symmetrical cyclohexyl substituent at the $\beta$-position restricts the values of the torsion angles $\phi\left(N-C^{\beta}\right)$ and $\theta\left(C^{\beta}-C^{\alpha}\right)$ to approximately gauche values $\left( \pm 60^{\circ}\right)$. Relatively few intramolecularly hydrogen bonded conformations are observed. In the dipeptide Boc- $\beta^{3,3} A c_{6} c-\beta^{3,3} A c_{6} c-N H M e$ a $C_{6}$ hydrogen bond is observed. In Piv-Pro- $\beta^{3,3} A c_{6} c$-NHMe a $C_{11}$ hydrogen bonded hybrid $\alpha \beta$ turn is characterized. In a majority of cases the amino group occupies the axial position in the cyclohexane ring. The conformations observed are compared with crystallographically observed structures for other $\beta$-residues, including $\beta^{2,2} A c_{6}$ c. (C) 2008 Wiley Periodicals, Inc. Biopolymers (Pept Sci) 90: 138-150, 2008.

Keywords: beta-peptide; beta3,3-disubstituted residue; peptide crystal structures; peptide conformation

Correspondence to: P. Balaram; e-mail: pb@mbu.iisc.ernet.in and N. Shamala; e-mail: shamala@physics.iisc.ernet.in

Contract grant sponsor: Council of Scientific and Industrial Research (CSIR), Department of Biotechnology, India

(C) 2008 Wiley Periodicals, Inc.
This article was originally published online as an accepted preprint. The "Published Online" date corresponds to the preprint version. You can request a copy of the preprint by emailing the Biopolymers editorial office at biopolymers@wiley. com

\section{INTRODUCTION}

here has been an explosive upsurge of interest in the structural properties of polypeptides containing $\beta$ and $\gamma$-amino acid residues. ${ }^{1-4}$ Research in this area has been fuelled by the observation of novel folded structures, stabilized by diverse intramolecular hydrogen bonds in oligo $\beta$ and $\gamma$ peptides and also in hybrid sequences containing $\alpha$-amino acid and their backbone homologated counterparts. ${ }^{5-14}$ Conformational diversity may be anticipated on backbone homologation of amino acid residues since the available torsional space for the residues is enhanced. In the case of $\beta$-residues the number of torsional variables is three $(\phi, \theta, \psi)$ while it is four $\left(\phi, \theta_{1}, \theta_{2}\right.$, $\psi)$ in the case of $\gamma$-residues. The accommodation of $\beta$ and $\gamma$ residues into hydrogen bonded folded peptide structures was determined in early studies of oligo $\beta$-peptides and hybrid sequences containing $\beta$ - and $\gamma$-residues. ${ }^{5-11}$

A detailed understanding of the conformational properties of $\alpha$-amino acids containing sequences has become possible only as a result of the enormous body of structural information that has been derived from X-ray diffraction studies of peptides and proteins. Indeed, every protein high-resolution structure determined provides valuable conformational information on peptides as well. In contrast, structural information on sequences containing $\beta$ and $\gamma$-residues must necessarily be obtained by X-ray diffraction studies of synthetic peptides. As part of ongoing studies aimed at developing simple stereochemically constrained $\beta$ and $\gamma$ residues as building blocks in peptide design, we have investigated the 


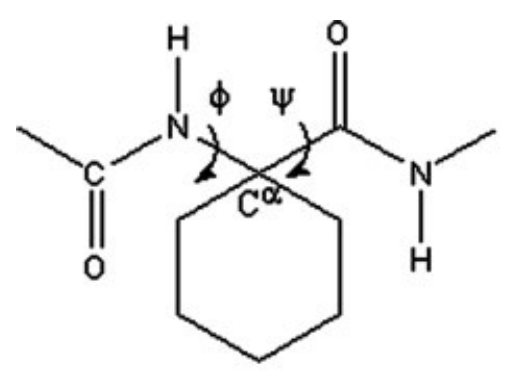

$\mathrm{Ac}_{6} \mathrm{C}$

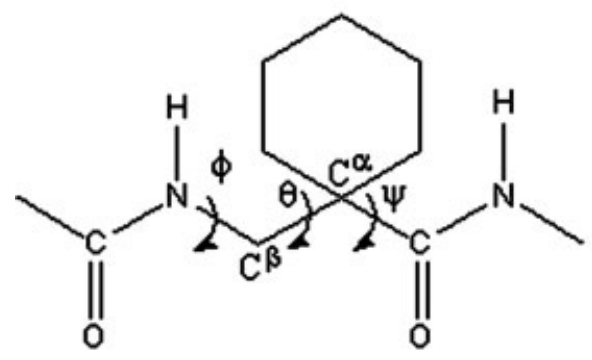

$\beta^{2, A c_{6} \mathrm{C}}$
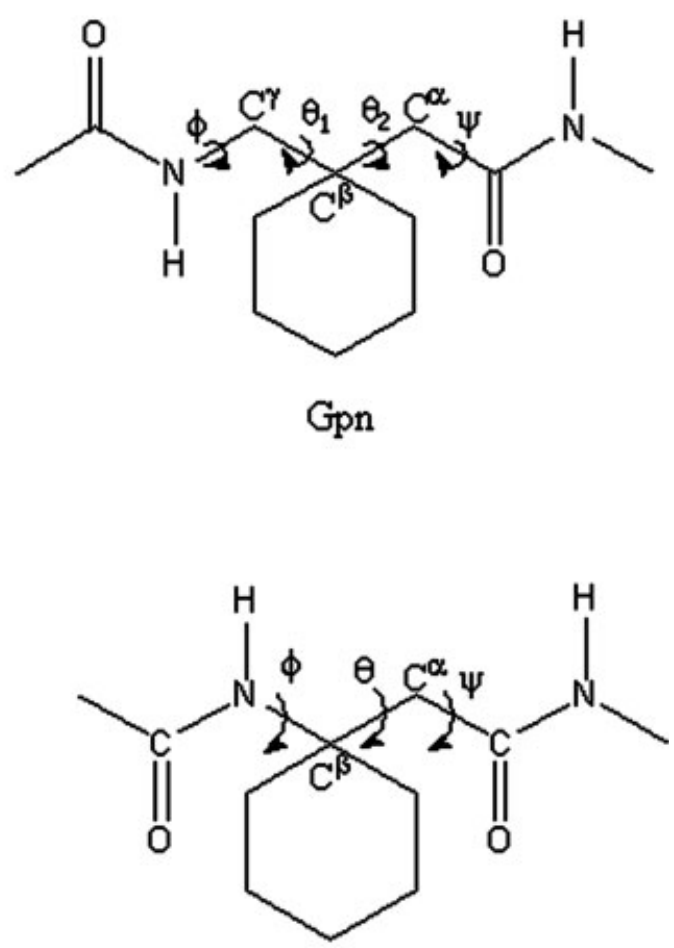

$\beta^{3,3} \mathrm{Ac}_{6} \mathrm{C}$

FIGURE 1 Chemical structures of $A_{6} \mathrm{c}$, Gpn and $\beta \mathrm{Ac}_{6} \mathrm{C}$ residues.

conformational properties of peptides containing the achiral $\beta, \beta$-disubstituted $\beta$-residue, 1 -aminocyclohexaneacetic acid $\left(\beta^{3,3} \mathrm{Ac}_{6} \mathrm{c}\right.$, Figure 1$) . \beta^{3,3} \mathrm{Ac}_{6} \mathrm{c}$ can be considered as a homologue of the well-studied $\alpha$-residue 1 -aminocyclohexane-1-carboxylic acid ${ }^{15-17}\left(\mathrm{Ac}_{6} \mathrm{c}\right)$ and $\gamma$-residue, 1-aminomethylcyclohexaneacetic acid (gabapentin). ${ }^{18,19}$ Preliminary structural studies have been reported by Seebach et al. on the isomeric residue, 1-aminomethylcyclohexanecarboxylic acid $\left(\beta^{2,2} \mathrm{Ac}_{6} \mathrm{c}\right) .^{20}$

\section{RESULTS}

Table I lists the backbone torsion angles determined in crystals for the free amino acid, $\beta^{3,3} \mathrm{Ac}_{6} \mathrm{c}$, protected derivatives and di- and tri-peptides containing this residue. In an overwhelming majority of the structures the amino group occupies an axial orientation with respect to the cyclohexane ring, while the $\mathrm{CH}_{2}-\mathrm{CO}$ group adopts the equatorial position. The only exceptions are the free amino acid (1), amino acid hydrochloride (2) and the C-terminus residue in the dipeptide, Boc- $\beta^{3,3} \mathrm{Ac}_{6} \mathrm{c}-\beta^{3,3} \mathrm{Ac}_{6} \mathrm{c}-\mathrm{NHMe}$ (10). In these three cases an intramolecular 6-atom $\left(\mathrm{C}_{6}\right) \mathrm{N}-\mathrm{H} \cdots$. OC hydrogen bond is observed. Figure 2 illustrates the observed molecular conformation in these three examples. The $\mathrm{C}_{6}$ hydrogen bond in a $\beta$-residue may be considered as a formal backbone expansion of the $\mathrm{C}_{5}$ hydrogen bond proposed in the fully extended structure of $\alpha$-peptides. ${ }^{21}$ It may be noted that the free $\alpha$ - amino acid analogue $\mathrm{Ac}_{6} \mathrm{c}$ has the amino group in an equatorial orientation. ${ }^{17}$ Interestingly, a survey of the peptides containing $\mathrm{Ac}_{6} \mathrm{C}$ residue reveals that the amino group adopts an axial orientation in almost all cases, an observation similar to that reported here for the $\beta^{3,3} \mathrm{Ac}_{6} \mathrm{C}$ residue.

The structure of the model sequence Piv-Pro- $\beta^{3,3} \mathrm{Ac}_{6} \mathrm{c}-$ NHMe has been shown to form a $C_{11}$ hydrogen bond in which the $\alpha \beta$-turn is an expanded version of the Type II $\beta$ turn in an $\alpha \alpha$-segment. ${ }^{22}$ This unit has been used to generate a $\beta$-hairpin structure with an $\alpha \beta$ hybrid nucleating turn. The peptide Boc-Aib-Pro- $\beta^{3,3} \mathrm{Ac}_{6} \mathrm{C}-\mathrm{NHMe}$ (11) was synthesized in order to test the competing possibilities of -Aib-Pro- $\mathrm{C}_{10}$ hydrogen bond formation versus - Pro- $\beta^{3,3} \mathrm{Ac}_{6} \mathrm{C}-\mathrm{C}_{11}$ hydrogen bond formation. Figure 3 illustrates the observed molecular conformation of the protected tripeptide Boc-Aib-Pro$\beta^{3,3} \mathrm{Ac}_{6} \mathrm{c}-\mathrm{NHMe}(\mathbf{1 1})$ in crystals. Peptide $\mathbf{1 1}$ forms an Aib-Pro Type III $\beta$-turn stabilized by a single $\mathrm{C}_{10}(4 \rightarrow 1)$ intramolecular hydrogen bond. The peptide Boc- $\beta$ Pro- $\beta^{3,3} \mathrm{Ac}_{6} \mathrm{c}-\mathrm{OMe}$, (12) containing two $\beta$-residues, adopts an extended conformation devoid of intramolecular hydrogen bonds. In this case the $\beta$ Pro residue adopts a trans conformation about the 
Table I Backbone Torsion Angles (deg) and Orientation of Substituents on the $\beta^{3,3} \mathrm{Ac}_{6} \mathrm{c}$ Residue Determined in Crystal Structures

\begin{tabular}{|c|c|c|c|c|c|}
\hline Compounds & $\phi$ & $\theta$ & $\psi$ & $\omega$ & Amino group \\
\hline$\beta^{3,3} \mathrm{Ac}_{6} \mathrm{c} 1$ & & 60.1 & & - & Equatorial \\
\hline$\beta^{3,3} \mathrm{Ac}_{6} \mathrm{c} . \mathrm{HCl} 2$ & & 55.4 & 168.1 & & Equatorial \\
\hline $\mathrm{Ac}-\beta^{3,3} \mathrm{Ac}_{6} \mathrm{c}-\mathrm{OH} 3$ & -61.8 & -60 & -161.7 & - & Axial \\
\hline Piv- $\beta^{3,3} \mathrm{Ac}_{6} \mathrm{C}-\mathrm{OH} 4 \mathrm{Mol} 1$ & 61.9 & 65.2 & 161.0 & - & Axial \\
\hline Mol 2 & -60.1 & -64.1 & -158.5 & - & Axial \\
\hline Boc- $\beta^{3,3} \mathrm{Ac}_{6} \mathrm{c}-\mathrm{OH} 5$ & 60.3 & 44.8 & $82.5(-96.3)^{\mathrm{a}}$ & - & Axial \\
\hline Boc- $\beta^{3,3} \mathrm{Ac}_{6} \mathrm{C}-\mathrm{NHMe} 6$ & 49.5 & 43.2 & -145.1 & -176.6 & Axial \\
\hline Boc- $\beta^{3,3} \mathrm{Ac}_{6} \mathrm{c}-\mathrm{Aib}-\mathrm{OMe} 7 \mathrm{Mol} 1$ & -63.7 & -63.6 & -105.5 & 170.3 & Axial \\
\hline Mol 2 & -58.1 & -70.2 & -117.9 & 173.9 & Axial \\
\hline Boc-Aib- $\beta^{3,3} \mathrm{Ac}_{6} \mathrm{c}-\mathrm{OMe} 8$ & -59.8 & -63.2 & 91.9 & -177.0 & Axial \\
\hline Boc- $\beta^{3,3} \mathrm{Ac}_{6} \mathrm{c}-\beta^{3,3} \mathrm{Ac}_{6} \mathrm{c}-\mathrm{OMe} 9\left(\beta^{3,3} \mathrm{Ac}_{6} \mathrm{c} 1\right)$ & -60.8 & -176.2 & 106.6 & 169.8 & Axial \\
\hline$\left(\beta^{3,3} \mathrm{Ac}_{6} \mathrm{c} 2\right)$ & 62.1 & 53.6 & 82.7 & 178.3 & Axial \\
\hline Boc- $\beta^{3,3} \mathrm{Ac}_{6} \mathrm{C}-\beta^{3,3} \mathrm{Ac}_{6} \mathrm{C}-\mathrm{NHMe} 10\left(\beta^{3,3} \mathrm{Ac}_{6} \mathrm{c} 1\right)$ & 71.9 & 72.0 & -73.6 & 176.6 & Axial \\
\hline$\left(\beta^{3,3} \mathrm{Ac}_{6} \mathrm{c} 2\right)$ & -168.7 & -58.0 & -118.0 & -179.7 & Equatorial \\
\hline Boc-Aib-Pro- $\beta^{3,3} \mathrm{Ac}_{6} \mathrm{c}-\mathrm{NHMe} 11$ & 62.0 & 58.7 & 107.7 & 176.3 & Axial \\
\hline Boc- $\beta$ Pro- $\beta^{3,3} \mathrm{Ac}_{6} \mathrm{c}-\mathrm{OMe} 12$ & 60.2 & 62.6 & $-43.4(59.6)^{\mathrm{a}}$ & $171.7(-167.7)^{\mathrm{a}}$ & Axial \\
\hline
\end{tabular}

${ }^{a}$ The values given in parentheses correspond to the alternate conformation observed at the disordered C-terminus.

$\mathrm{C}^{\alpha}-\mathrm{C}^{\beta}$ bond $\left(\theta=180^{\circ}\right)$ resulting in a stretched peptide backbone. The N-terminus urethane blocking group adopts the less frequent cis conformation $\left(\omega=-0.12^{\circ}\right) .^{23}$ The structures of two dipeptide esters containing $\beta^{3,3} \mathrm{Ac}_{6} \mathrm{c}$ are illustrated in Figure 4. No intramolecular hydrogen bonds are observed in these structures. Interestingly, in both the cases there is close approach of a carbonyl oxygen to an axial $\mathrm{C}-\mathrm{H}$ bond on a cyclohexane ring. The observed parameters $\mathrm{H} \cdot \mathrm{O}=2.70-2.75 \AA, \mathrm{C} \cdot \mathrm{O} \mathrm{O}=3.65-3.70 \AA, \mathrm{C}-\mathrm{H} \cdots \mathrm{O}$ $=168^{\circ}-170^{\circ}$ are suggestive of a potentially stabilizing interaction, although the $\mathrm{C}-\mathrm{H}$ groups are not polarized by the presence of electronegative substituents. Figure 5 illustrates the observed conformations in five derivatives and peptides containing $\beta^{3,3} \mathrm{Ac}_{6} \mathrm{c}$. In all the cases the structures do not possess any intramolecular hydrogen bonds. In two cases, Boc- $\beta^{3,3} \mathrm{Ac}_{6} \mathrm{c}-\mathrm{OH} 5$ and the dipeptide Boc- $\beta^{3,3} \mathrm{Ac}_{6} \mathrm{c}-\beta^{3,3} \mathrm{Ac}_{6} \mathrm{C}-$ NHMe 10, the N-terminal urethane group adopts a cis geometry $\left(\omega=14.5^{\circ}\right.$ for $5 ; \omega=-9.1^{\circ}$ for 10$)$. Inspection of the crystal packing arrangement in both cases reveals registry of facing urethane groups through the formation of a pair of hydrogen bonds between molecules related by a centre of inversion (see Figure 6).

\section{DISCUSSION}

Conformations of the $\beta^{3,3} \mathrm{Ac}_{6} \mathrm{c}$ Residue in Peptides

The sterically allowed regions of conformational space available to amino acid residues can be significantly reduced by substitution at backbone carbon atoms. In the case of $\alpha$-amino acid residues the reduction in accessible conformational space is best illustrated by comparing the Ramachandran map for glycyl, alanyl, and $\alpha$-aminoisobutyryl (Aib) residues, in which substituents are progressively introduced at the tetrahedral $\mathrm{C}^{\alpha}$ carbon atom. ${ }^{24}$ By extension, limitations of allowed conformations can also be imposed in the case of $\beta$-amino acid residues by substitution at the $\mathrm{C}^{\alpha}$ and $\mathrm{C}^{\beta}$ atoms. The seminal work of Seebach et al. has provided an entry to studies of the structural chemistry of substituted $\beta$-residues. ${ }^{1,2}$ In an alternative approach, Gellman and collaborators have introduced conformational constraints in the $\beta$-residues by covalently bridging the $\mathrm{C}^{\alpha}$ and $\mathrm{C}^{\beta}$ positions, as exemplified by their studies of 2-aminocycloalkanecaboxylic acids. ${ }^{7-9}$ In the present study we have systematically determined the solid state conformations of several derivatives and peptides containing the $\beta, \beta$-disubstituted achiral residue, $\beta^{3,3} \mathrm{Ac}_{6} \mathrm{c}$. This residue can be compared to both its lower and higher homologues $\mathrm{Ac}_{6} \mathrm{C}$ and gabapentin (Gpn), respectively. In the case of the $\alpha$-residue, $A_{6} \mathrm{c}$, constraints are imposed on both the $\phi$ and $\psi$ torsion angles, limiting the residue to helical regions of conformational space $\left(\phi= \pm 60^{\circ}, \psi= \pm 30^{\circ}\right) .{ }^{15-17}$ In the case of the $\gamma$-residue, Gpn, the symmetrically positioned $\beta, \beta$-dialkyl substituents restricts the torsion angle $\theta_{1}\left(C^{\gamma}-C^{\beta}\right)$ and $\theta_{2}\left(C^{\beta}-C^{\alpha}\right)$ to gauche conformations, resulting in the stabilization of several unique intramolecularly hydrogen bonded conformations. $^{19}$ 
(a)

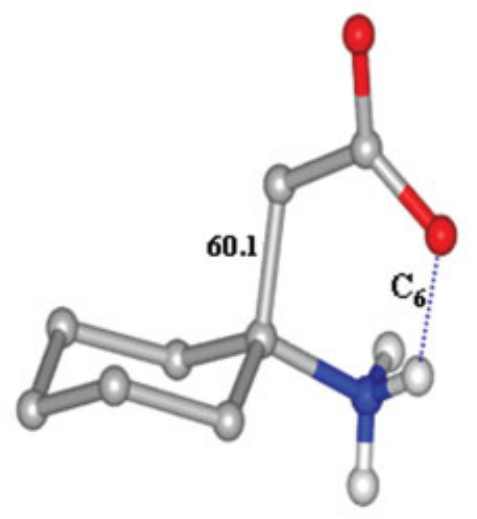

(b)

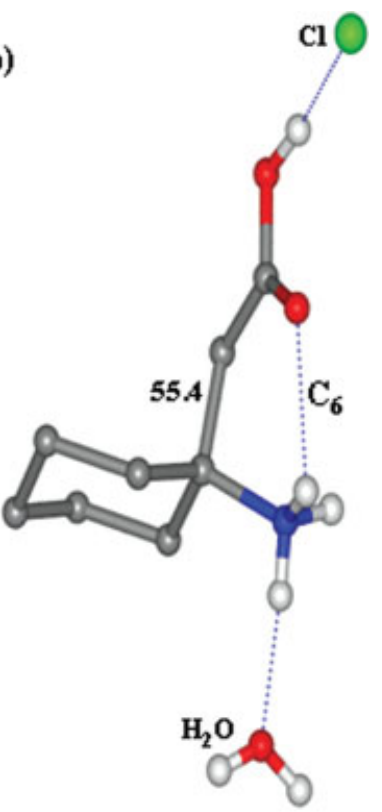

(c)

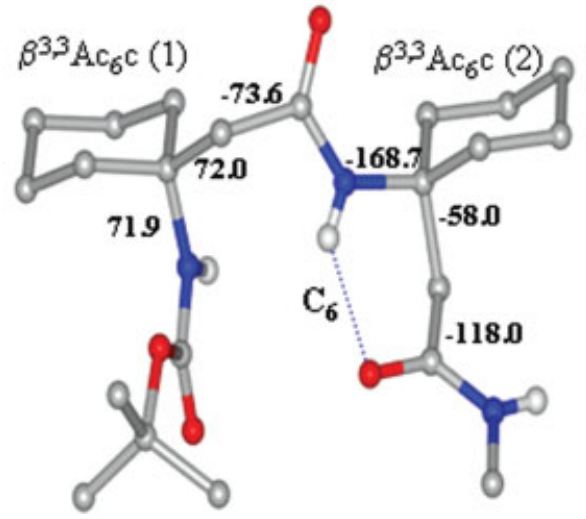

FIGURE 2 Molecular conformation in crystals of (a) the free amino acid $\beta^{3,3} \mathrm{Ac}_{6} \mathrm{c}$ 1, (b) $\beta^{3,3} \mathrm{Ac}_{6} \mathrm{c}$ hydrochloride 2 and (c) the dipeptide Boc- $\beta^{3,3} \mathrm{Ac}_{6} \mathrm{c}-\beta^{3,3} \mathrm{Ac}_{6} \mathrm{c}-\mathrm{NHMe} 10 . \mathrm{C}_{6}$ hydrogen bond parameters, $1, \mathrm{~N} \cdots \mathrm{O}=2.72 \AA$; $\mathrm{H} \cdots \mathrm{O}=1.94 \AA$; $<\mathrm{N}-\mathrm{H} \cdots \mathrm{O}=137.8^{\circ} ; 2, \mathrm{~N} \cdots \mathrm{O}=$ $2.80 \AA$; $\mathrm{H} \cdots \mathrm{O}=2.24 \AA ; \mathrm{N}^{\circ}-\mathrm{H} \cdots \mathrm{O}=118.6^{\circ} ; \mathbf{1 0}, \mathrm{N} \cdots \mathrm{O}=2.77 \AA$; $\mathrm{H} \cdots \mathrm{O}=2.07 \AA$; $<\mathrm{N}-\mathrm{H} \cdots \mathrm{O}=139.2^{\circ}$.

In $\beta^{3,3} \mathrm{Ac}_{6} \mathrm{c}$, the dialkyl substituents impose restrictions on the torsion angles $\phi$ and $\theta$. Interestingly, in many of the structures determined, no intramolecular hydrogen bonds are observed. The exceptions are the dipeptide $\mathrm{Boc}^{-\beta^{3,3} \mathrm{Ac}_{6} \mathrm{C}-}$ $\beta^{3,3} \mathrm{Ac}_{6} \mathrm{C}$-NHMe, (10) in which residue 2 adopts a $\mathrm{C}_{6}$ hydrogen bonded conformation. $\mathrm{A}_{11}$ hydrogen bonded expanded analogue of a $\beta$-turn structure is also observed in the hybrid peptide Piv-Pro- $\beta^{3,3} \mathrm{Ac}_{6} \mathrm{c}$-NHMe. Figure 7 illustrates the observed backbone hydrogen bonded conformations involving $\beta^{3,3} \mathrm{Ac}_{6} \mathrm{C}$, and also provides for comparison, hydrogen bonded conformations observed in the isomeric residue, $\beta^{2,2} \mathrm{Ac}_{6} \mathrm{C}$ studied by Seebach et al. ${ }^{20}$ The $\mathrm{C}_{6}$ conformation has been observed in both $\beta^{2,2} A c_{6} \mathrm{c}$ and $\beta^{3,3} A c_{6} \mathrm{c}$ residues. Inspection of the torsion angles in the two illustrated examples suggests that the hydrogen bond interaction can be obtained with a gauche conformation about the $\mathrm{C}^{\alpha}-\mathrm{C}^{\beta}$ bond $(\theta)$ and with one of the other dihedral angles, $\phi$ or $\psi$ in fully extended conformation $\left(\phi \sim 180^{\circ}, \psi \sim 180^{\circ}\right)$. Similar hydrogen bond interaction is also observed in the case of the free amino acid (1) and hydrochloride salt (2). The $\mathrm{C}_{6}$ conformation in model peptides has also been shown to be energetically favorable by quantum mechanical calculations, despite the poor geometry of the hydrogen bond. ${ }^{25}$ The $\mathrm{C}_{6}$ conformation of $\beta$-residues may be viewed as expanded analogue of the $\mathrm{C}_{5}$ conformation 
(a)

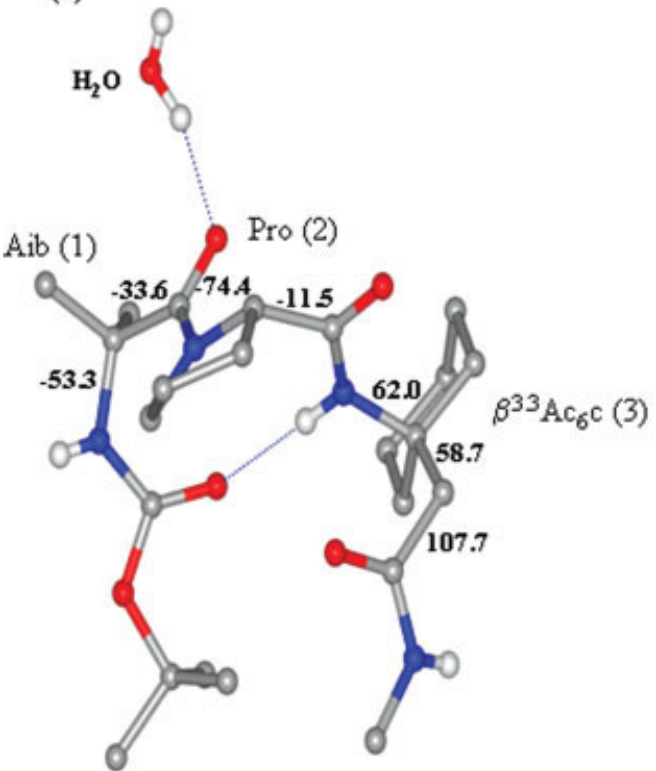

(b)

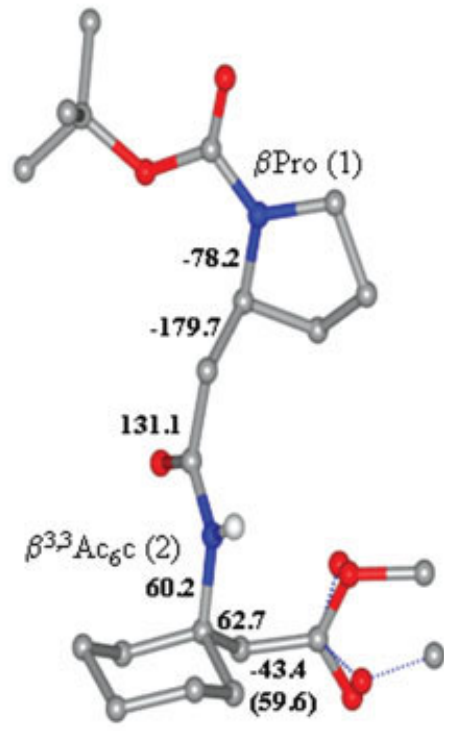

FIGURE 3 Molecular conformation in crystals of (a) Boc-Aib-Pro- $\beta^{3,3} \mathrm{Ac}_{6} \mathrm{c}-\mathrm{NHMe} 11$ and (b) Boc- $\beta$ Pro- $\beta^{3,3} \mathrm{Ac}_{6} \mathrm{c}-\mathrm{OMe} 12$. The $\mathrm{C}=\mathrm{O}(\mathrm{OMe})$ group is disordered over two positions with refined occupancy ratio 0.59:0.41.

observed in fully extended $\alpha$-peptides as exemplified in the crystal structures of homo oligomers of $\alpha, \alpha$-diethyl and dipropyl glycines. ${ }^{21}$ In $\alpha$-residues another well-characterized intramolecularly hydrogen bonded structure is the $\mathrm{C}_{7}$ of $\gamma$-turn structure. ${ }^{26}$ In this case a 7 atom hydrogen bonded ring is formed by interaction of $\mathrm{C}=\mathrm{O}_{\mathrm{i}-1} \cdots \mathrm{HN}_{\mathrm{i}+1}$. The $\beta$ residue analogue of this structure would be a $\mathrm{C}_{8}$ conformation. At present the $\mathrm{C}_{8}$ structure $\left(\phi=-111^{\circ}, \theta=69.6^{\circ}, \psi=\right.$ (a)

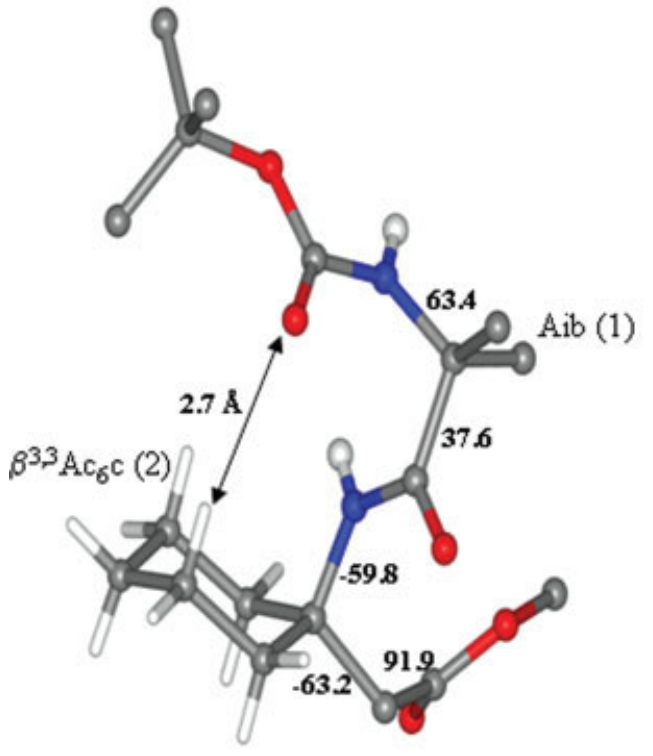

(b)

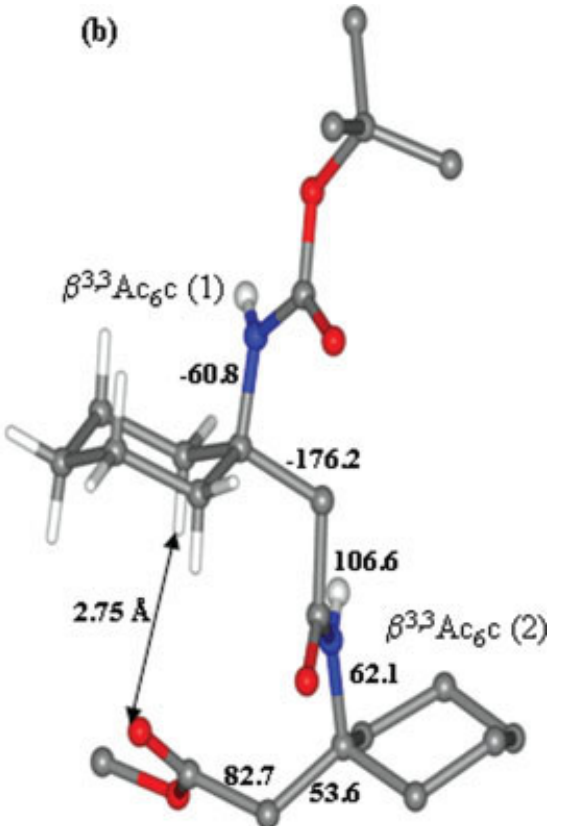

FIGURE 4 Conformation in crystals of (a) Boc-Aib- $\beta^{3,3} \mathrm{Ac}_{6} \mathrm{c}-\mathrm{OMe} 8$ and (b) Boc- $\beta^{3,3} \mathrm{Ac}_{6} \mathrm{C}-$ $\beta^{3,3} \mathrm{Ac}_{6} \mathrm{c}$-OMe 9. 
(a)

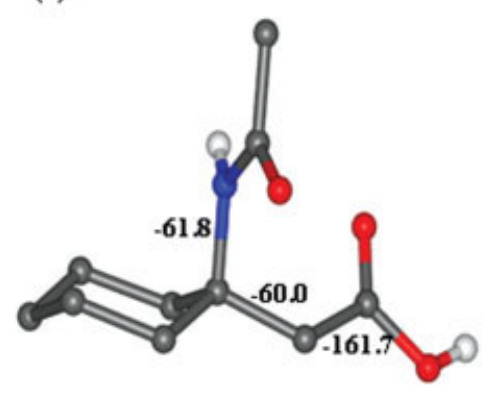

(c)

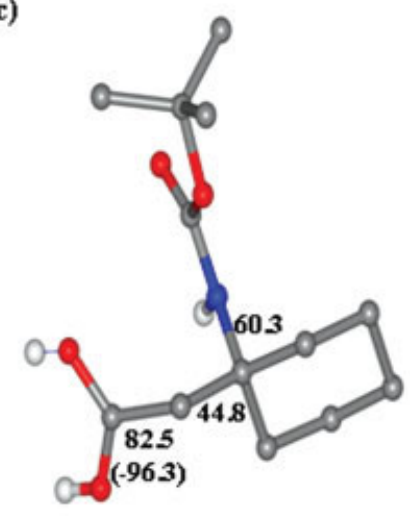

(b)
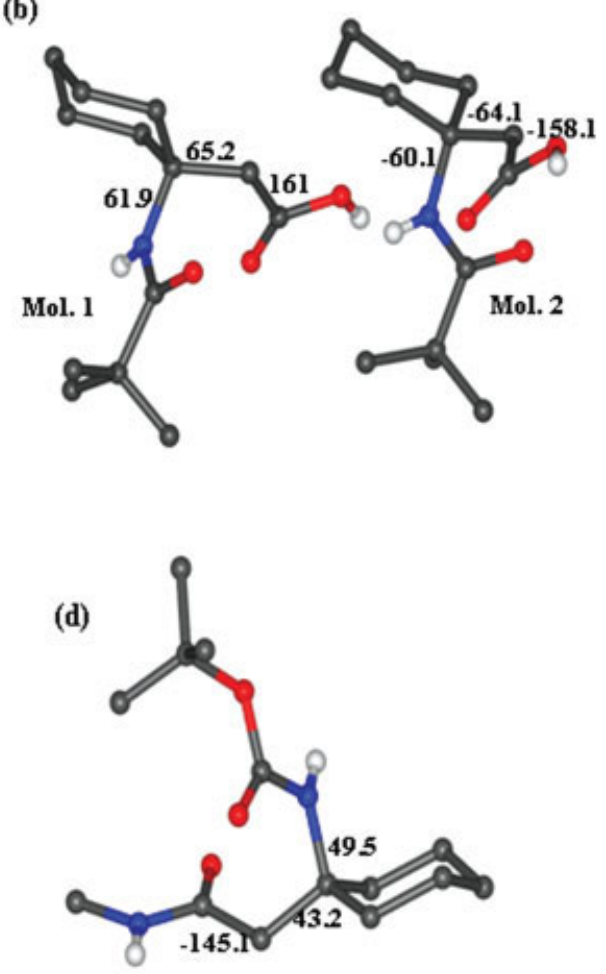

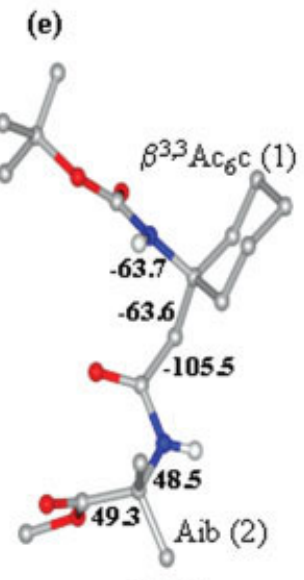

Mol. 1

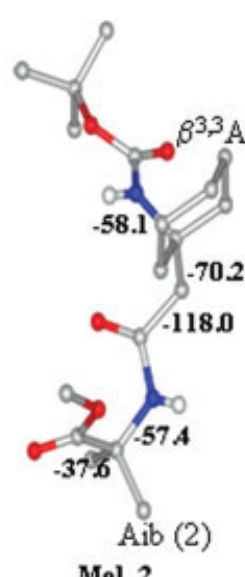

Mol. 2

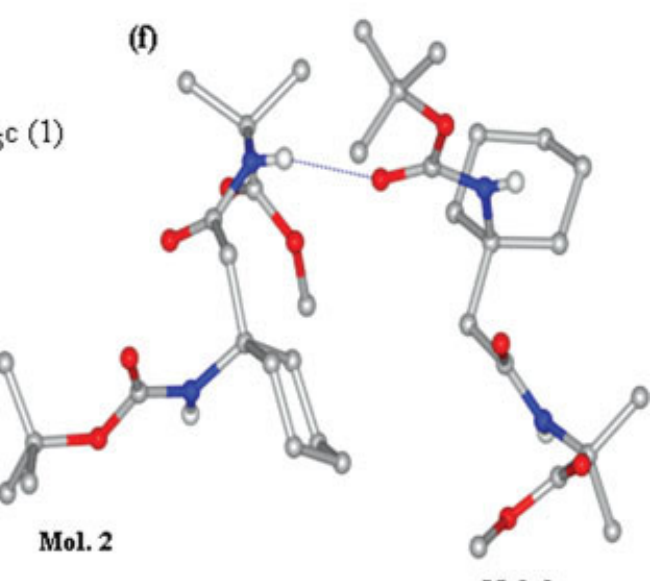

Mol. 1

FIGURE 5 Molecular conformation in crystals observed for (a) $\mathrm{Ac}-\beta^{3,3} \mathrm{Ac}_{6} \mathrm{c}-\mathrm{OH} 3$, (b) Piv$\beta^{3,3} \mathrm{Ac}_{6} \mathrm{c}-\mathrm{OH} 4$, (c) Boc- $\beta^{3,3} \mathrm{Ac}_{6} \mathrm{c}-\mathrm{OH} 5$, (d) Boc- $\beta^{3,3} \mathrm{Ac}_{6} \mathrm{c}-\mathrm{NHMe}$. The hydrogen atom of the carboxylic acid group of $\mathbf{5}$ is disordered over the two oxygen atoms with equal occupancy. (e) Two independent molecules in the asymmetric unit of Boc- $\beta^{3,3} \mathrm{Ac}_{6} \mathrm{c}-\mathrm{Aib}-\mathrm{OMe} 7$ crystals. (f) A view of the asymmetric unit of 7 .

$4.5^{\circ}$ ) has been observed in the solid state only in crystal structures of $\beta^{2,2} \mathrm{Ac}_{3} \mathrm{c}$ residues ${ }^{27}$ and has not been reported either in $\beta^{2,2} \mathrm{Ac}_{6} \mathrm{c}$ or $\beta^{3,3} \mathrm{Ac}_{6} \mathrm{c}$ residues. The $\mathrm{C}_{8}$ conformation has been advanced for the $\beta^{2,2} \mathrm{Ac}_{6} \mathrm{c}$ residue in a solution NMR study of a chemotactic tripeptide analogue. ${ }^{28}$ The $\mathrm{C}_{8}$ structure has also been postulated on the basis of NMR analysis of cyclic pentapeptide containing $\beta$-residues. ${ }^{29}$

In the crystal structure of the protected dipeptide ester $\mathbf{9}$, there is no intramolecular hydrogen bond observed for the $\beta^{3,3} \mathrm{Ac}_{6} \mathrm{c}-\beta^{3,3} \mathrm{Ac}_{6} \mathrm{c}$ segment (see Figure 4). In contrast, in the 

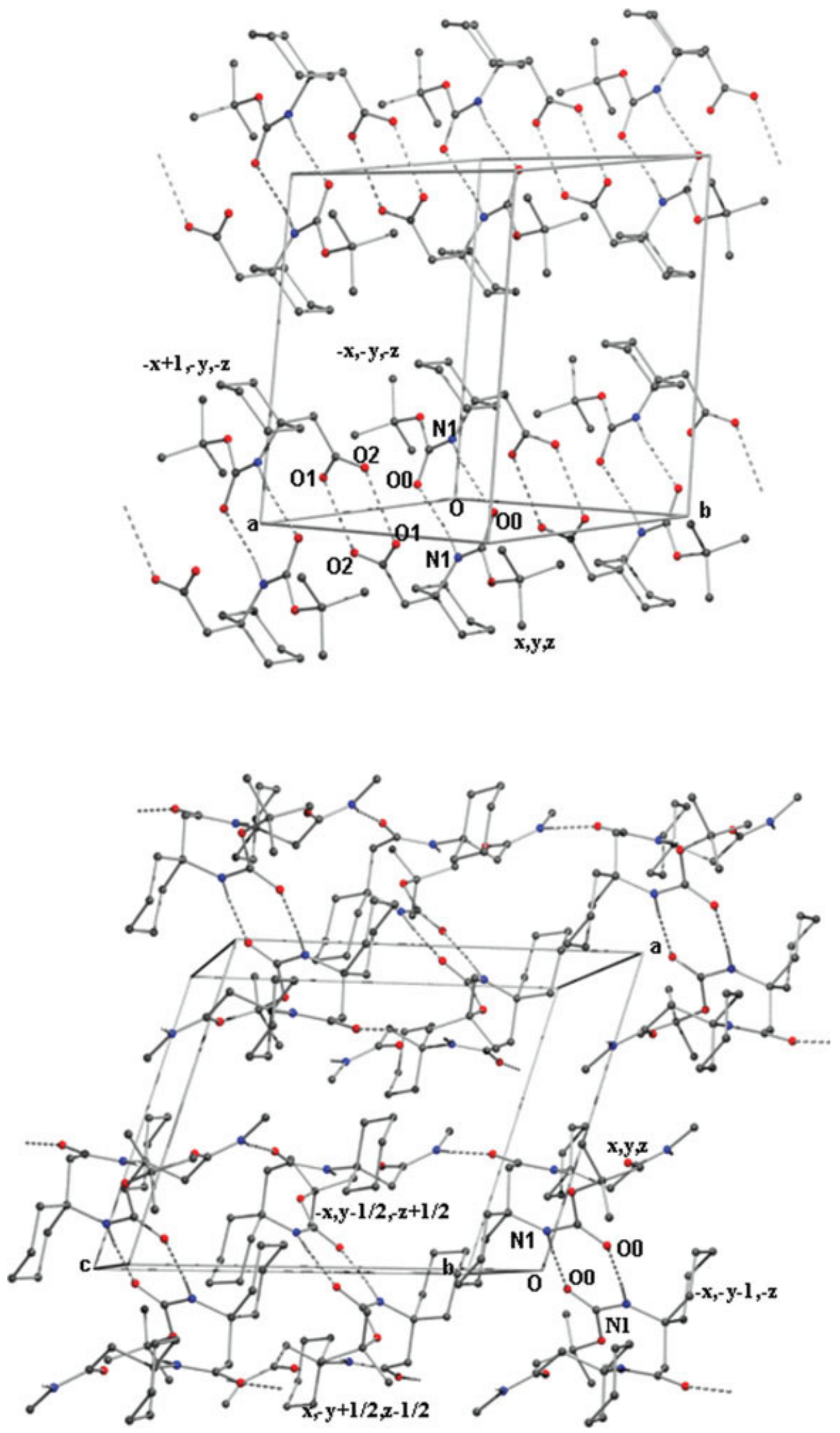

FIGURE 6 Packing of molecules in Boc- $\beta^{3,3} \mathrm{Ac}_{6} \mathrm{c}-\mathrm{OH} 5$ (top) and Boc- $\beta^{3,3} \mathrm{Ac}_{6} \mathrm{c}-\beta^{3,3} \mathrm{Ac}_{6} \mathrm{c}-\mathrm{NHMe}$ 10 (bottom) crystals. 
(a)

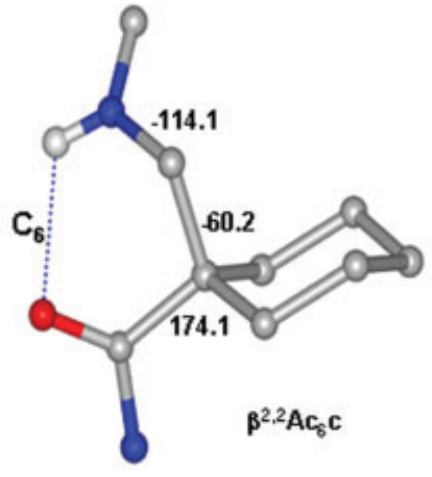

(c)

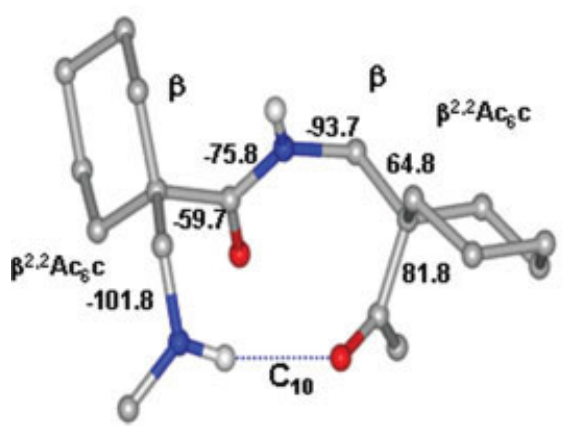

(b)

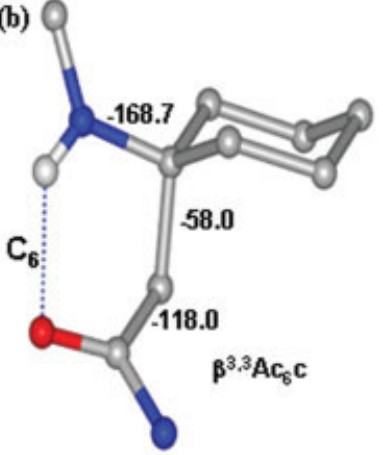

(d)

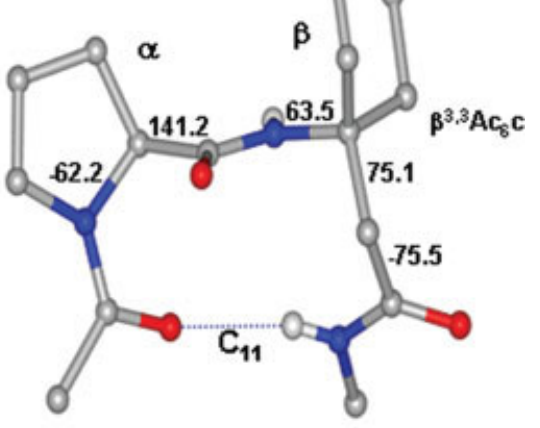

FIGURE 7 Intramolecularly hydrogen bonded backbone conformations in $\beta^{2,2} \mathrm{Ac}_{6} \mathrm{C}$ and $\beta^{3,3} \mathrm{Ac}_{6} \mathrm{c}$ peptides. (a) A $\mathrm{C}_{6}$ hydrogen bond turn observed at $\beta^{2,2} \mathrm{Ac} \mathrm{c}_{6} \mathrm{C}$ (1) in the crystal structure of Boc- $\beta^{2,2} \mathrm{Ac}_{6} \mathrm{c}-\beta^{2,2} \mathrm{Ac}_{6} \mathrm{c}-\beta^{2,2} \mathrm{Ac}_{6} \mathrm{c}-\mathrm{OMe}^{20}$ (b) $\mathrm{C}_{6}$ hydrogen bonded turn formed at $\beta^{3,3} \mathrm{Ac}_{6} \mathrm{c}$ (2) in the crystal structure of peptide 10. (c) $\mathrm{A} \mathrm{C}_{10}(\beta \beta)$ turn formed by residues 2 and 3 in the crystal structure of Boc- $\beta^{2,2} \mathrm{Ac}_{6} \mathrm{c}-\beta^{2,2} \mathrm{Ac}_{6} \mathrm{C}-\beta^{2,2} \mathrm{Ac}_{6} \mathrm{C}-\mathrm{OMe}{ }^{20}(\mathrm{~d}) \mathrm{C}_{11}(\alpha \beta)$ hydrogen bond characterized in the crystal structure of Piv-Pro- $\beta^{3,3} \mathrm{Ac}_{6} \mathrm{C}-\mathrm{NHMe}{ }^{22}$

case of the tripeptide Boc- $\beta^{2,2} \mathrm{Ac}_{6} \mathrm{c}-\beta^{2,2} \mathrm{Ac}_{6} \mathrm{c}-\beta^{2,2} \mathrm{Ac}_{6} \mathrm{c}-\mathrm{OMe}$, residues 2 and 3 form a $\mathrm{C}_{10}$ hydrogen bond with reversed polarity, i.e., $\mathrm{NH}_{(\mathrm{i})} \cdots \mathrm{OC}_{(\mathrm{i}+1)}{ }^{20}$

In the dipeptide Piv-Pro- $\beta^{3,3} \mathrm{Ac}_{6} \mathrm{C}-\mathrm{NHMe}$, the $\beta^{3,3} \mathrm{Ac}_{6} \mathrm{C}$ residue adopts $i+2$ position of an expanded version of type II $\beta$-turn. All the three backbone conformational angles are approximately in the region for gauche conformation. This type of hybrid $\alpha \beta$ turn is positioned to nucleate a peptide hairpin. Indeed, solution NMR studies support a $\beta$-hairpin in the octapeptide, Boc-Leu-Phe-Val- ${ }^{\mathrm{D}}$ Pro- $\beta^{3,3}{ }^{\mathrm{Ac}} \mathrm{c}_{6} \mathrm{c}$-LeuPhe-Val-OMe. ${ }^{22}$ These examples suggest that $\beta^{3,3} \mathrm{Ac}_{6} \mathrm{c}$ residue can be positioned in specific intramolecularly hydrogen bonded structures.

\section{Backbone Conformations of $\boldsymbol{\beta}$-Residues in Peptides}

The determination of the crystal structures of several peptides containing the $\beta^{3,3} \mathrm{Ac}_{6} \mathrm{C}$ residue provides an opportunity to analyze torsion angle preferences for $\beta$-resi-

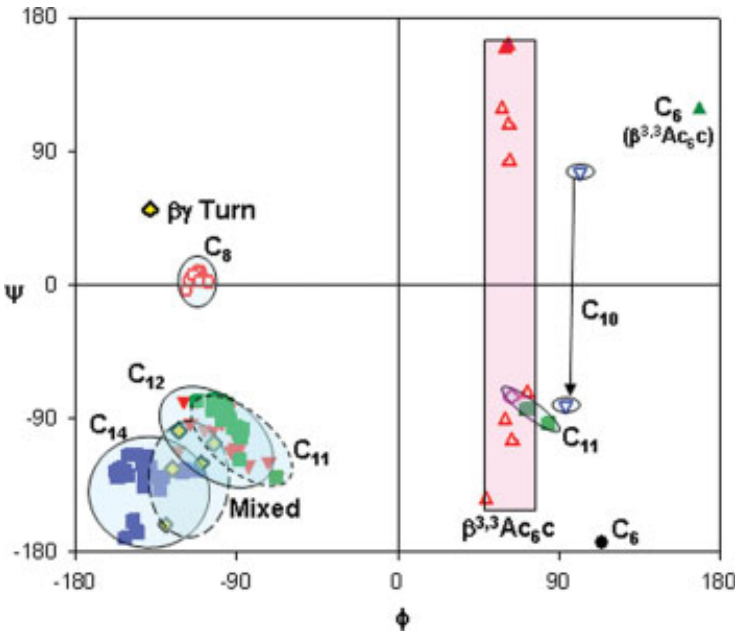

FIGURE 8 Two-dimensional scatter plot in $\phi-\psi$ space $\left(\theta=+60^{\circ}\right)$ for intramolecularly hydrogen bonded $\beta$-residues determined in several peptide crystal structures. Specific intramolecular hydrogen bond types and the space for non-hydrogen bonded $\beta^{3,3} \mathrm{Ac}_{6} \mathrm{c}$ residue are marked. The arrow indicates the position of the $\mathrm{N}$ - and C-terminus residues of the $\beta \beta \mathrm{C}_{10}$ turn. 
dues. An understanding of the conformational biases imposed by backbone substitution patterns is essential for using $\beta$-residues, in a rational manner, in the design of specifically folded peptides. The conformational analysis of $\alpha$-amino acid containing peptides has benefited enormously by the use of the Ramachandran map, which allows a simple representation of individual residue conformations in two-dimensional $\phi-\psi$ space. The introduction of an additional torsional variable $\theta$ in the case of $\beta$ residues necessitates the use of three-dimensional maps for a complete description. To simplify the problem of representation, we have used two-dimensional $\phi-\psi$ plots for fixed values of $\theta$, which is largely constrained to either gauche $\left(\theta \sim 60^{\circ}\right)$ or trans $\left(\theta \sim 180^{\circ}\right)$ conformations. Figure 8 shows a two-dimensional scatter plot in $\phi-\psi$ space for $\theta=+60^{\circ}$. All the experimentally observed $\beta^{3,3} \mathrm{Ac}_{6} \mathrm{c}$ residues are marked. In addition, the observed $\phi-\psi$ distributions for various types of intramolecularly hydrogen bonded structures observed in the case of all reported $\beta$-residues are indicated. The clusters marked correspond to specific hydrogen bond types. The $\mathrm{C}_{6}$ and $\mathrm{C}_{8}$ structures are formed by a single $\beta$-residue and differ in hydrogen bond directionality. The $\mathrm{C}_{12}$ structure corresponds to a $\beta \beta$ segment with conventional hydrogen bond polarity, which is an expanded analogue of the type III turn in $\alpha$-peptides. ${ }^{30}$ The $\mathrm{C}_{10}$ and $\mathrm{C}_{14}$ structures are formed by $\beta \beta$ and $\beta \beta \beta$ segments with reversed hydrogen bond polarity. The helices arising from repetition of $\mathrm{C}_{12}$ and $\mathrm{C}_{14}$ hydrogen bond type were initially characterized crystallographically by Gellman and collaborators. ${ }^{7-9}$ The $\mathrm{C}_{11}$ and mixed clusters correspond to hybrid sequences containing both $\beta$ and $\alpha$ residues. For example, a $C_{11}$ hydrogen bond can be formed in a $\alpha \beta$ segment as exemplified by the structure of peptide Piv-Pro- $\beta^{3,3} \mathrm{Ac}_{6} \mathrm{C}$ NHMe (see Figure 7). Larger hydrogen bonded rings $C_{13}$, $\mathrm{C}_{14}, \mathrm{C}_{15}$, and $\mathrm{C}_{16}$ can also be formed in $\beta \gamma, \alpha \alpha \beta, \alpha \beta \beta$, and $\beta \gamma \alpha$ segments, respectively, as exemplified in the crystal structures of Boc-Leu-Aib-Val- $\beta$ Gly- $\gamma$ Abu-Leu-AibVal-Ala-Leu-Aib-OMe, ${ }^{11} \quad$ Boc-Leu-Aib-Val- $\beta$ Gly- $\gamma$ AbuLeu-Aib-Val-OMe, ${ }^{11}$ Boc-Leu-Phe-Val-Aib- $\beta$ Phe-Leu-PheVal-OMe, ${ }^{31}$ and Boc-Val-Ala-Phe-Aib- $\beta$ Val- $\beta$ Phe-Aib-ValAla-Phe-Aib-OMe. ${ }^{32}$ The following features of the scatter plot in Figure 8 merit mention:

1. For $\beta^{3,3} \mathrm{Ac}_{6} \mathrm{c}$, both $\phi$ and $\theta$ values are restricted to the region of $\pm 60^{\circ}$ and have the same sign. In contrast, the formation of a $\mathrm{C}_{12}$ helix requires that $\phi$ and $\theta$ are close to the gauche conformation, but have opposite signs. This clearly suggests that the $\beta^{3,3} \mathrm{Ac}_{6} \mathrm{C}$ residue is precluded from forming many of the intramolecularly hydrogen bonded structures observed in oligo $\beta$-peptides.

2. A noteworthy feature is the characterization of two $\mathrm{C}_{11}$ conformations in $\alpha \beta$-segments, which results in an expanded analogue of the conventional $\beta$-turns. These two structures correspond to a change of $\sim 180^{\circ}$ at the $\phi$ value of the $\beta$-residue, which arise due to a flip of the central peptide unit linking the $\alpha$ and $\beta$ amino acids. A similar flip of the central linking peptide unit relates the type I and type II $\beta$-turn conformations in $\alpha \alpha$ segments. ${ }^{30,33}$ This feature is also observed for two residue turns in hybrid $\beta \gamma$ segments $\left(\mathrm{C}_{13}\right.$ hydrogen bond). In Figure 8 , the point in the upper left quarter labeled as a $\beta \gamma$ turn corresponds to the $\mathrm{C}_{13}$ turn observed in Boc- $\beta$ Phe-Gpn-Phe-OMe. ${ }^{19}$ This is a nonhelical turn analogous to the type II $\beta$-turn in $\alpha \alpha$ sequences. The helical $\beta \gamma$ turns cluster in the lower left quadrant.

3. The $\beta \beta \mathrm{C}_{10}$ turn observed in the $-\beta^{2,2} \mathrm{Ac}_{6} \mathrm{c}-\beta^{2,2} \mathrm{Ac}_{6} \mathrm{c}-$ segment by Seebach et al., ${ }^{20}$ which has inverted hydrogen bond polarity, requires distinct conformations at the two $\beta$-residues, that differ in $\psi$ values by $\sim 180^{\circ}$.

The unsubstituted parent $\beta$ residue $\beta$-glycine ( $\beta$ hGly, also referred in the earlier literature as the $\beta$-alanyl residue ${ }^{2}$ ) may be taken as the starting point for analyzing conformational space accessible to amino acids with homologated backbones. Experimentally determined crystal structures have captured the $\beta$ Gly residue in extended conformations in $\beta$-strands and in folded conformation in turns and helices. ${ }^{34}$ Conformational limitations can be imposed by introducing substituents at the $\alpha$ and $\beta$ positions. Substitution results in creating chiral centers adding another dimension to the conformational problem. The introduction of symmetrical substituents at the 2 and 3 positions as in $\beta^{2,2} \mathrm{Ac}_{6} \mathrm{C}$ and $\beta^{3,3} \mathrm{Ac}_{6} \mathrm{C}$ results in achiral residues in which two of the three conformational angles are restricted to a limited range of values. Figure 9 illustrates examples of some of the chiral and multiply substituted $\beta$-residues whose conformations have been determined in several distinct peptide crystal structures. Constraints introduced by backbone cyclization provide an entry into $\beta$-residues with well-defined conformational preferences as exemplified by 2-aminocyclopentanecarboxylic acid (ACPC), 2-aminocyclohexanecarboxylic acid (ACHC) and nipecotic acid, which have been investigated by Gellman and coworkers. ${ }^{4}$

The use of $\beta, \gamma$, and higher $\omega$ amino acids in the design of hybrid peptide sequences provides an opportunity to mimic the folded structures observed in proteins and natural poly- 

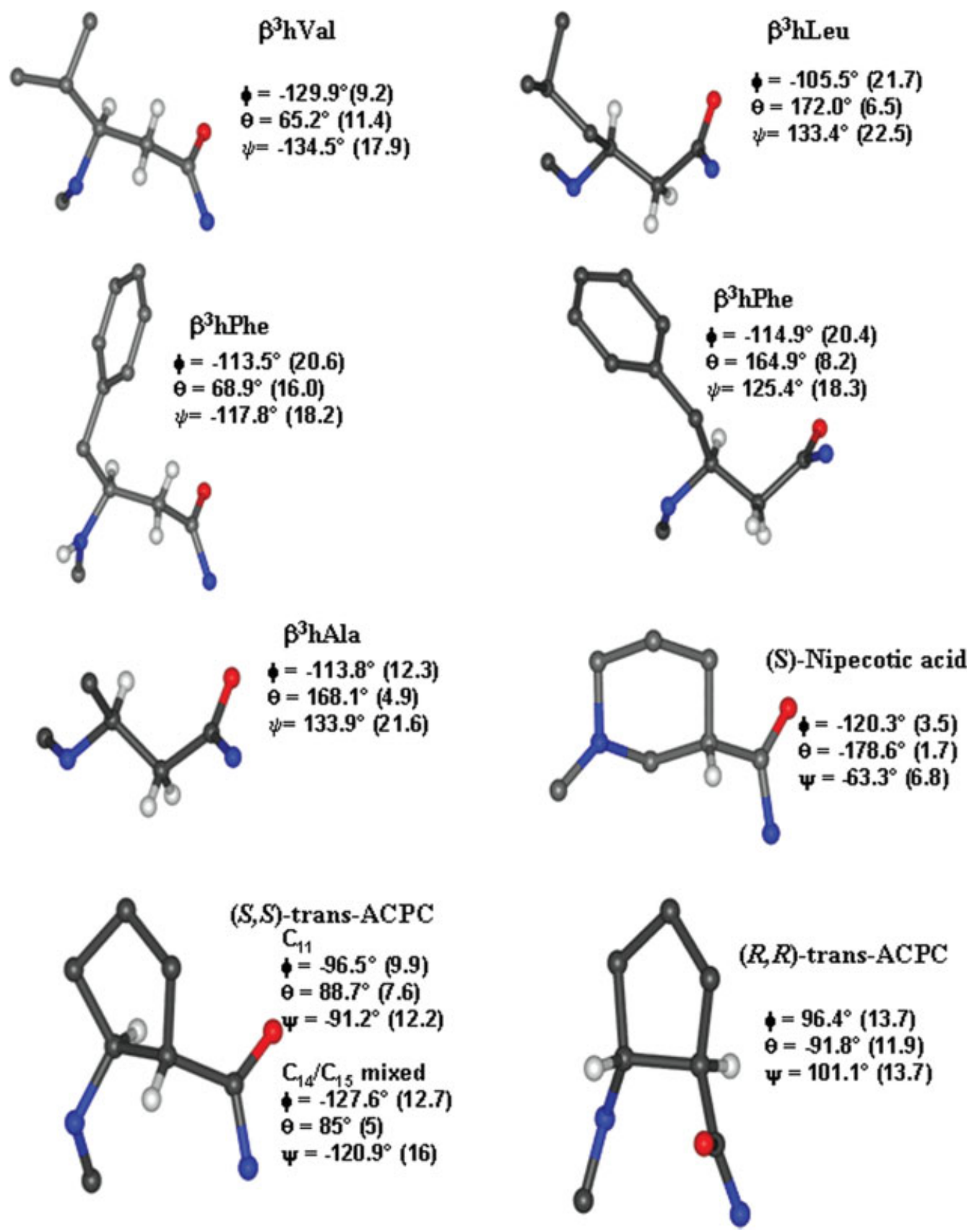

FIGURE 9 Experimentally determined torsion angles for chiral and multiply substituted $\beta$ residues in specific back bone conformations. The torsion angles listed are averaged over the observed structures and the e.s.ds are shown in parentheses. The number of structures used are $\beta^{3} \mathrm{hVal}^{5,32,35-37} 8, \beta^{3} \mathrm{hLeu}^{5,36,37} 5, \beta^{3} \mathrm{hPhe}(\theta \text { gauche })^{31,32,35} 4, \beta^{3} \mathrm{hPhe}(\theta \text { trans })^{38-40} 10$, $\beta^{3} \mathrm{hAla}^{5,35} 5$, (S)-Nipecotic acid ${ }^{41,42} 3$, (S,S)-trans $\mathrm{ACPC}^{12-14} 27\left(\mathrm{C}_{11}\right), 4\left(\mathrm{C}_{14} / \mathrm{C}_{15}\right),(\mathrm{R}, \mathrm{R})$ trans $\mathrm{ACPC}^{9} 12$.

peptides. Unnatural synthetic backbones can provide stability in biological situations. The creation of novel hydrogen bonded structures and folding patterns which have no analogues in the world of natural polypeptides is also an enticing possibility. The development and applications of $\beta$ and higher $\omega$ amino acids with well-characterized conformational propensities will advance the area of hybrid peptide structures. 

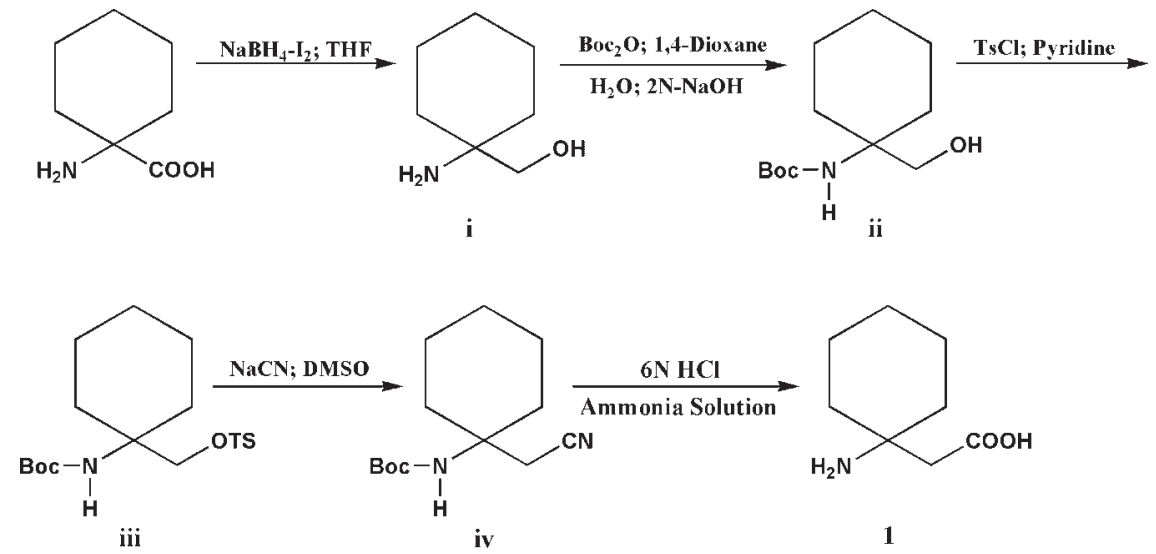

SCHEME 1 Synthesis of 1-aminocyclohexaneacetic acid $\left(\beta^{3,3} \mathrm{Ac}_{6} \mathrm{C}\right)$.

\section{MATERIALS AND METHODS}

\section{Synthesis of $\beta^{3,3} \mathrm{Ac}_{6} \mathrm{c}$ (Scheme 1)}

1-aminocyclohexane-1-carboxylic acid $\left(\mathrm{Ac}_{6} \mathrm{C}\right)$ was reduced to the amino alcohol (i) following the procedure of McKennon et al. ${ }^{43}$ $7.15 \mathrm{~g}(50 \mathrm{mmol})$ of 1-aminocyclohexane-1-carboxylic acid $\left(\mathrm{Ac}_{6} \mathrm{C}\right)$, $3.78 \mathrm{~g} \mathrm{NaBH}_{4}(100 \mathrm{mmol})$ and $100 \mathrm{ml}$ dry THF were placed in a two necked round bottom flask. The flask was cooled to $0^{\circ} \mathrm{C}$ in an ice bath. A solution of $12.7 \mathrm{~g}$ ( $50 \mathrm{mmol})$ of iodine in $25 \mathrm{ml}$ of dry THF was added drop wise over 30 min under stirring, resulting in vigorous evolution of hydrogen. After addition of the iodine was complete and gas evolution had ceased, the flask was heated to reflux for $24 \mathrm{~h}$ and then cooled to room temperature and methanol was added until the mixture became clear. After 30 min stirring, the solvent was removed in vacuo yielding a white paste, which was dissolved by addition of $75 \mathrm{ml}$ of $20 \%$ aqueous $\mathrm{KOH}$. The solution was stirred for $8 \mathrm{~h}$ and extracted with $4 \times 75 \mathrm{ml}$ of dichloromethane. The organic extracts were dried over anhydrous $\mathrm{Na}_{2} \mathrm{SO}_{4}$ and concentrated under vacuum, yielded $5.93 \mathrm{~g}$ of the amino alcohol (i) as a white gum, which was directly used for further reaction.

Boc-derivative (ii): $5.8 \mathrm{~g}$ ( $45 \mathrm{mmol}$ ) of compound $\mathbf{i}$ was prepared as Boc derivative by the treatment of $\mathbf{i}$ with di-tert-butyldicarbonate in 1,4-dioxane-water (1:1) in presence of $2 \mathrm{~N}-\mathrm{NaOH}$. Standard work up yielded $8.75 \mathrm{~g}$ of solid (ii, Yield $85 \%$ ).

Tosyl derivative (iii): $8.0 \mathrm{~g}$ ( $35 \mathrm{mmol}$ ) of Boc protected amino alcohol ii was dissolved in freshly distilled $50 \mathrm{ml}$ of pyridine and the solution was stirred at $0^{\circ} \mathrm{C}$, while $13.3 \mathrm{~g}(70 \mathrm{mmol})$ of p-toluenesulfonyl chloride was slowly added. The reaction mixture was stored at $-4^{\circ} \mathrm{C}$ for 5 days and $100 \mathrm{ml}$ of ice cold water was added and extracted with $3 \times 50 \mathrm{ml}$ of diethyl ether. The organic layer was subsequently washed with $4 \mathrm{~N} \mathrm{HCl}$ followed by saturated aqueous $\mathrm{NaHCO}_{3}$ and brine solution. The organic layer was dried over $\mathrm{MgSO}_{4}$ and evaporated to yield the Boc protected tosylate iii. Yield: $93.6 \%(12.65 \mathrm{~g})$.

Nitrile derivative (iv): To $11.58 \mathrm{~g}$ ( $30 \mathrm{mmol})$ of compound iii in $30 \mathrm{ml}$ of DMSO, $2.94 \mathrm{~g}(60 \mathrm{mmol})$ of $\mathrm{NaCN}$ was added with stirring. The reaction mixture was left at room temperature for 48 hours and then added $50 \mathrm{ml}$ of water and extracted with diethyl ether. The ether layer was evaporated and the residue was purified by column chromatography on silica gel using hexane-ethyl acetate (9:1) to afford 3.85g (54\%) of compound iv.

$\beta^{3,3} \mathbf{A c}_{6} \mathbf{c}(1): 3.85 \mathrm{~g}$ of compound iv was refluxed in $20 \mathrm{ml}$ of $6 \mathrm{~N}-\mathrm{HCl}$ for $48 \mathrm{~h}$. The reaction mixture was cooled to room temperature and extracted with $3 \times 10 \mathrm{ml}$ of ethyl acetate. Organic layer was discarded and aqueous layer was neutralized with ammonia solution, until alkaline. The solution was concentrated. On cooling, crystals of $\beta^{3,3} \mathrm{Ac}_{6} \mathrm{c}$ (1) were obtained, which gave ninhydrin positive test (Yield $2.1 \mathrm{~g}$ ).

\section{Peptide Synthesis}

Peptides were synthesized by classical solution phase methods. The N-terminal was protected by either tert-butyloxycarbonyl (Boc) or Pivaloyl (Piv) group, while C-terminal was protected as a methyl ester $(\mathrm{OMe})$. The peptide-NHMe was prepared by passing methylamine gas in solution of peptide-OMe in methanol under dry condition. Deprotection of $\mathrm{N}$ - and C- terminus was achieved with $98 \%$ formic acid and $2 \mathrm{~N} \mathrm{NaOH} / \mathrm{MeOH}$, respectively. Couplings were mediated by using either DCC/HOBt or mix anhydride procedure. Peptides were purified by medium pressure liquid chromatography (MPLC) on a $\mathrm{C}_{18}$ reverse phase column-using methanol-water gradient. The homogeneity of the peptides was checked by analytical RP-HPLC. The peptides were further characterized by ${ }^{1} \mathrm{H}$ NMR recorded on a Bruker AMX-400 $\mathrm{MHz}$ spectrometer and also through electrospray ionisation mass spectrometry (ESI-MS), which were recorded on HP-1100 Mass Spectrometer.

\section{Structure Solution and Refinement}

Single crystals suitable for X-ray diffraction were obtained by slow evaporation of concentrated solutions in aqueous/organic solvents. Table II summarizes the unit cell parameters and the final $R$-values for all the 12 compounds. X-ray data were collected at room temperature on a Bruker AXS SMART APEX CCD diffractometer, using Mo $\mathrm{K}_{\alpha}$ radiation $(\lambda=0.71073 \AA)$. $\omega$-Scan type was used. Structures were solved by direct methods in SHELXS- $97^{44}$ or by Patterson heavy atom method in DIRDIF ${ }^{45}$ (for 2). Refinement was carried out against $F^{2}$ with full matrix least square methods in SHELXL- 


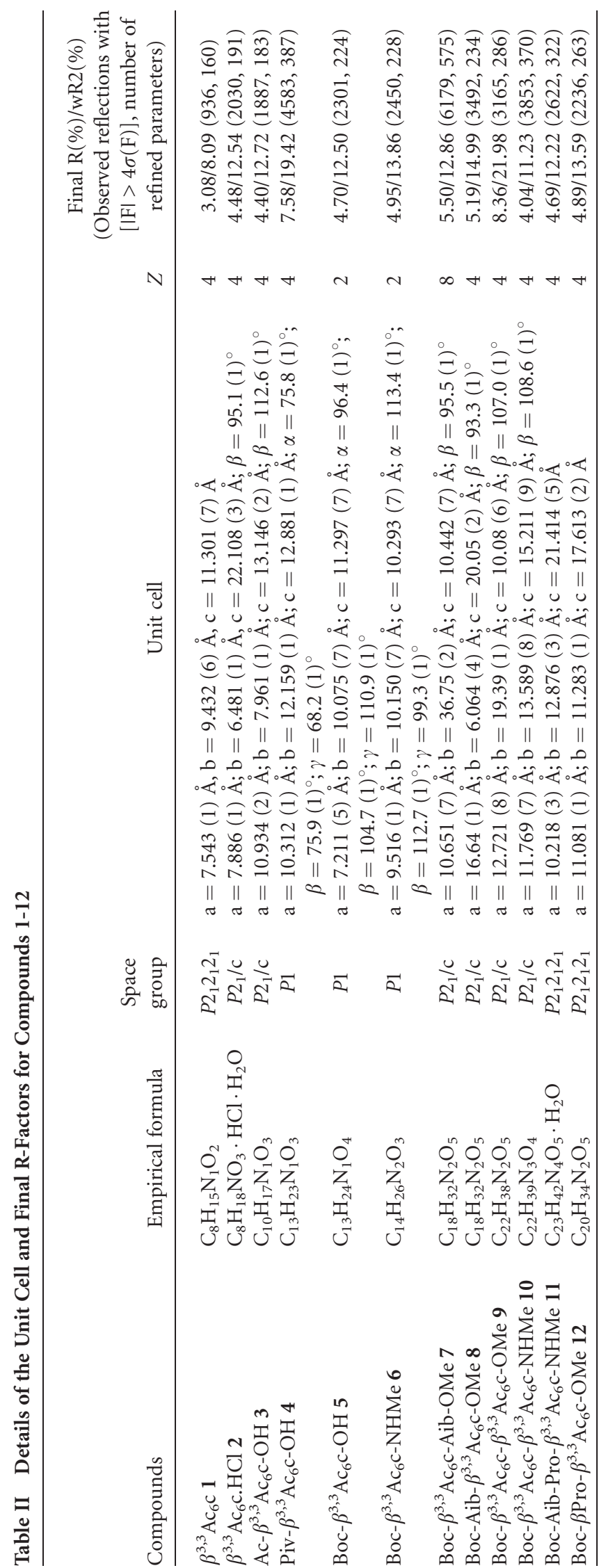

97. ${ }^{46}$ Notably, The free amino acid $\mathbf{1}$ crystallized in the non-centrosymmetric space group $\mathrm{P} 2{ }_{1} 2_{1} 2_{1}$, while the amino acid derivatives and achiral peptides crystallized in centrosymmetric space groups. For 2, the R-factor (16\%) and the residual electron density $\left(1.3 \mathrm{e}^{-3}\right)$ were high after anisotropic refinement. Therefore the presence of twinning was tested with the program ROTAX, ${ }^{47}$ which suggested the twin law $(-100 / 0-10 / 0.501)$, corresponding to $2-$ fold rotation about [ $\left[\begin{array}{lll}1 & 0 & 4\end{array}\right]$ direct lattice direction. The application of this matrix to the data brought down the R-factor to $4.48 \%$ with fraction of two components refined being 0.7 and 0.3 . The C-terminal COOMe group of Boc- $\beta$ Pro- $\beta^{3,3} \mathrm{Ac}_{6} \mathrm{c}-\mathrm{OMe}$ (12) is disordered over two positions with refined occupancy 0.59:0.41. The hydrogen atoms were located from difference Fourier maps wherever possible and were refined isotropically. Remaining hydrogen atoms were fixed geometrically in idealized positions and were refined as riding over the atoms to which they are bonded. In the case of 5 , two positions could be located for the hydrogen atom of the carboxylic acid group. These two positions were isotropically refined with half occupancy. The crystallographic coordinates for the structures are deposited at the Cambridge Crystallographic Data Centre with deposition numbers CCDC 670218-670229. These data can be obtained free of charge via www.ccdc.cam.ac.uk/conts/retrieving.html (or from the Cambridge Crystallographic Data Centre, 12 Union Road, Cambridge CB21EZ, UK; fax: (+44) 1223-336-033; or e-mail: deposit@ccdc.cam.ac.uk).

P.G.V. thanks the CSIR for a Senior Research Fellowship. X-ray diffraction data were collected on the CCD facility funded under the IRHPA program of the Department of Science and Technology, India.

\section{REFERENCES}

1. Seebach, D.; Hook, D. F.; Glättli, A. Biopolymers (Peptide Sci) 2006, 84, 23-37.

2. Seebach, D.; Beck, A. K.; Bierbaum, D. J. Chem Biodiver 2004, 1, 1111-1239.

3. Roy, R. S.; Balaram, P. J Peptide Res 2004, 63, 279-289.

4. Cheng, R. P.; Gellman, S. H.; DeGrado, W. F. Chem Rev 2001, 101, 3219-3232.

5. Seebach, D.; Overhand, M.; Kühnle, F. N. M.; Martinoni, B. Helv Chim Acta 1996, 79, 913-941.

6. Seebach, D.; Matthews, J. L. Chem Commun 1997, 2015-2022.

7. Appella, D. H.; Christianson, L. A.; Karle, I. L.; Powell, D. R.; Gellman, S. H. J Am Chem Soc 1996, 118, 13071-13072.

8. Appella, D. H.; Christianson, L. A.; Klein, D. A.; Powell, D. R.; Huang, X.; Barchi J. J. Jr.; Gellman, S. H. Nature 1997, 387, 381-384.

9. Appella, D. H.; Christianson, L. A.; Klein, D. A.; Richards, M. R.; Powell, D. R.; Gellman, S. H. J Am Chem Soc 1999, 121, 7574-7581.

10. Banerjee, A.; Balaram, P. Curr Sci 1997, 73, 1067-1077.

11. Karle, I. L.; Pramanik, A.; Banerjee, A.; Battacharjya, S.; Balaram, P. J Am Chem Soc 1997, 119, 9087-9095.

12. Schmitt, M. A.; Choi, H. S.; Guzei, I. A.; Gellman, S. H. J Am Chem Soc 2005, 127, 13130-13131.

13. Schmitt, M. A.; Choi, H. S.; Guzei, I. A.; Gellman, S. H. J Am Chem Soc 2006, 128, 4538-4539. 
14. Choi, S. H.; Guzei, I. A.; Gellman, S. H. J Am Chem Soc 2007, 129, 13780-13781.

15. Toniolo, C.; Benedetti, E. Macromolecules 1991, 24, 4004-4009.

16. Pavone, V.; Benedetti, E.; Barone, V.; Di Blasio, B.; Lelj, F.; Pedone, C.; Santini, A.; Crisma, M.; Bonora, G. M.; Toniolo, C. Macromolecules 1988, 21, 2064-2070.

17. Paul, P. K. C.; Sukumar, M.; Bardi, R.; Piazzessi. A. M.; Valle, G.; Toniolo, C.; Balaram, P. J Am Chem Soc 1986, 108, 6363-6370.

18. Ananda, K.; Aravinda, S.; Vasudev, P. G.; Raja, K. M. P.; Sivaramakrishnan, H.; Nagarajan, K.; Shamala, N.; Balaram, P. Curr Sci 2003, 85, 1002-1011.

19. Vasudev, P. G.; Ananda, K.; Chatterjee, S.; Aravinda, S.; Shamala, N.; Balaram, P. J Am Chem Soc 2007, 129, 4039-4048.

20. Seebach, D.; Abele, S.; Sifferlen, T.; Hänggi, M.; Gruner, S.; Seiler, P. Helv Chim Acta 1998, 81, 2218-2243.

21. Toniolo, C.; Benedetti, E. In Molecular Conformation and Biological Interactions; Balaram, P.; Ramaseshan, S., Eds. Indian Academy of Sciences: Bangalore, India, 1991; pp 511-521.

22. Rai, R.; Vasudev, P. G.; Ananda, K.; Raghothama, S.; Shamala, N.; Karle, I. L.; Balaram, P. Chem Eur J 2007, 13, 5917-5926.

23. Benedetti, E.; Pedone, C.; Toniolo, C.; Némethy, G.; Pottle, M. S.; Scheraga, H. A. Int J Pept Protein Res 1980, 13, 156-172.

24. Aravinda, S.; Shamala, N.; Roy, R. S.; Balaram, P. Proc Indian Acad Sci (Chem Sci) 2003, 115, 373-400.

25. Wu, Y.-D.; Wang, D.-P. J Am Chem Soc 1998, 120, 13485-13493.

26. Némethy, G.; Printz, M. P. Macromolecules 1972, 5, 755.

27. Abele, S.; Seiler, P.; Seebach, D. Helv Chim Acta 1999, 82, 15591571.

28. Mollica, A.; Paradisi, M. P.; Torino, D.; Spisani, S.; Lucente, G. Amino Acids 2006, 30, 453-459.

29. Schumann, F.; Müller, A.; Koksch, M.; Müller, G.; Sewald, N. J Am Chem Soc 2000, 122, 12009-12010.

30. Chatterjee, S.; Roy, R. S.; Balaram, P. J Roy Soc Interface 2006, $4,587-606$.

31. Ananda, K.; Vasudev, P. G.; Sengupta, A.; Raja, K. M. P.; Shamala, N.; Balaram, P. J Am Chem Soc 2005, 127, 16668-16674.
32. Roy, R. S.; Karle, I. L.; Raghothama, S.; Balaram, P. Proc Natl Acad Sci USA 2004, 101, 16478-16482.

33. Gunasekaran, K.; Gomathi, L.; Ramakrishnan, C.; Chandrasekhar, J.; Balaram, P. J Mol Biol 1998, 284, 1505-1516.

34. Sengupta, A.; Aravinda, S.; Shamala, N.; Raja, K. M. P.; Balaram, P. Org Biomol Chem 2006, 4, 4214-4222.

35. Sengupta, A.; Roy, R. S.; Sabareesh, V.; Shamala, N.; Balaram, P. Org Biomol Chem 2006, 4, 1166-1173.

36. Gopi, H. N.; Roy, R. S.; Raghothama, S.; Karle, I. L.; Balaram, P. Helv Chim Acta 2002, 85, 3313-3330.

37. Romanelli, A.; Garella, I.; Menchise, V.; Iacovino, R.; Saviano, M.; Montesarchio, D.; Didierjean, C.; Di Lello, P.; Rossi, F.; Benedetti, E. J Peptide Sci 2001, 7, 15-26.

38. Karle, I. L.; Gopi, H. N.; Balaram, P. Proc Natl Acad Sci USA 2001, 98, 3716-3719.

39. Karle, I. L.; Gopi, H. N.; Balaram, P. Proc Natl Acad Sci USA 2002, 99, 5160-5164.

40. Roy, R. S.; Gopi, H. N.; Raghothama, S.; Gilardi, R. D.; Karle, I. L.; Balaram, P. Peptide Sci 2005, 80, 787-799.

41. Chung, Y. J.; Christianson, L. A.; Stanger, H. E.; Powell, D. R.; Gellman, S. H. J Am Chem Soc 1998, 120, 10555-10556.

42. Chung, Y. J.; Huck, B. R.; Christianson, L. A.; Stanger, H. E.; Krauthäuser, S.; Powell, D. R.; Gellman, S. H. J Am Chem Soc 2000, 122, 3995-4004.

43. McKennon, M. J.; Meyers, A. I. J Org Chem 1993, 58, 35683571.

44. Sheldrick, G. M. SHELXS-97, A program for automatic solution of crystal structures; University of Göttingen: Göttingen, 1997.

45. Beurskens, P. T.; Beurskens, G.; de Gelder, R.; Garcia-Granda, S.; Gould, R. O.; Israel, R.; Smits, J. M. M. The DIRDIF-99 program system, Crystallography Laboratory; University of Nijmegen: The Netherlands.

46. Sheldrick, G. M. SHELXL-97, A program for crystal structure refinement; University of Göttingen: Göttingen, 1997.

47. Cooper, R. I.; Gould, R. O.; Parsons, S.; Watkin, D. J. J Appl Cryst 2002, 35, 168-174. 